www.periodicos.unimontes.br/index.php/caminhosdahistoria

\title{
LITERATURA E BANDITISMO SOCIAL: ANTÔNIO DÓ RETRATADO POR SAUL MARTINS E PETRÔNIO BRAZ
}

Rejane Meireles Amaral Rodrigues ${ }^{1}$

Recebido em: 16/04/2020

Aprovado em: 15/06/2020

Resumo: O presente artigo tem por objetivo analisar como a literatura apresentou a vida de Antônio Dó, que Após ser preso, por questões de demarcação de terra com seu vizinho, fugiu da delegacia em que estava preso. Recrutou um grupo de homens que, a partir de então, passou a segui-lo e juntos fizeram "justiça com as próprias mãos". Durante dezenove anos, Antônio Dó percorreu o Norte de Minas, Sul da Bahia e Sul de Goiás. O período em que seu bando existiu foi marcado por um excesso de intervenções na administração local por interesses particulares. Posterior aos acontecimentos a vida deste sertanejo foi retratada de várias formas, mas neste artigo vamos analisar a produção de Saul Martins e Petrônio Braz, e temos como problema de pesquisa entender se o contexto social aparece nas obras? Para realizar tal análise iremos comparar através de entrevistas como os autores produziram suas obras. Como conclusão entendemos que os dois autores, cada um ao seu modo, retratou o contexto em que se deu os acontecimentos da vida do Antônio Dó.

Palavras-chave: Literatura; Banditismo Social; Antônio Dó; Saul Martins; Petrônio Braz.

\section{LITERATURA Y BANDITISMO SOCIAL: ANTÔNIO DÓ RETRATADO POR SAUL MARTINS Y PETRÔNIO BRAZ}

Resumen: Este artículo tiene como objetivo analizar cómo la literatura presentó la vida de Antônio Dó, quien, después de ser arrestado, debido a la demarcación de tierras con su vecino, huyó de la estación de policía donde fue encarcelado. Reclutó a un grupo de hombres que, a partir de entonces, comenzaron a seguirlo y juntos hicieron "justicia con sus propias manos". Durante diecinueve años, Antônio Dó viajó por el norte de Minas, el sur de Bahía y el sur de Goiás. El período en el que su banda existió estuvo marcado por un exceso de intervenciones en la administración local para intereses privados. Después de los eventos, la vida de este compatriota fue retratada de varias maneras, pero en este artículo analizaremos la producción de Saul Martins y Petrônio Braz, y tenemos un problema de investigación para entender si el contexto social aparece en las obras? Para llevar a cabo dicho análisis, compararemos a través de entrevistas cómo los autores produjeron sus trabajos. Como conclusión, entendemos que los dos autores, cada uno a su manera, retrataron el contexto en el que tuvieron lugar los acontecimientos de la vida de Antônio Dó.

Palabras clave: Literatura, Bandidaje social, Antônio Dó, Saul Martins, Petrônio Braz.

\section{LITERATURE AND SOCIAL BANDITISM: ANTÔNIO DÓ PORTRAYED BY SAUL MARTINS AND PETRÔNIO BRAZ}

\footnotetext{
${ }^{1}$ Doutora em História Social pela UFU. Professora do Departamento de História da Universidade Estadual de Montes Claros (Unimontes-MG) e do PPGH - Unimontes. E-mail: rejane.meireles@gmail.com. ORCID: https://orcid.org/0000-0002-3387-5677.
} 
Abstract: This article aims to analyze how the literature presented the life of Antônio Dó, who, after being arrested, due to land demarcation with his neighbor, fled the police station where he was imprisoned. He recruited a group of men who, from then on, started to follow him and together they did "justice with their own hands". For nineteen years, Antônio Dó traveled the North of Minas, South of Bahia and South of Goiás. The period in which his band existed was marked by an excess of interventions in the local administration for private interests. After the events, the life of this countryman was portrayed in several ways, but in this article we will analyze the production of Saul Martins and Petrônio Braz, and we have as a research problem to understand if the social context appears in the works? To carry out such an analysis, we will compare through interviews how the authors produced their works. As a conclusion, we understand that the two authors, each in their own way, portrayed the context in which the events of Antônio Dó's life took place.

Keywords: Literature; Social Banditry; Antônio Dó; Saul Martins; Petrônio Braz.

\section{Introdução}

O Sertão do Norte de Minas é uma região rica em manifestações artísticas, baseadas em histórias de pessoas que se destacavam por atos de extrema violência ou bravura, tanto nas cidades quanto nas fazendas. No passado, estes atos, quando chegavam ao conhecimento de tropeiros, mascates e vaqueiros, eram contados e recontados e ganhavam fama. A imaginação das pessoas é fértil, cria e recria com base em histórias que ouvem, e os protagonistas destas histórias tornavam-se símbolos e referência de comportamentos. As histórias ganhavam a imaginação do povo e cada vez mais esses protagonistas ficavam conhecidos, fazendo assim a passagem que Certeau (CERTEAU, 1994) analisa como "conto filosófico" no qual "o homem ordinário é o locutor", e este "produz" arte "ordinária" que é retratada da oralidade para a escrita.

Iniciaremos assim, uma análise da "produção cultural", alimentada pela história de um fazendeiro que viveu na cidade de São Francisco, localizada no Norte de Minas Gerais, no início do século XX, conhecido como Antônio Dó. Sua vida teria sido pacata, como a de qualquer outro sertanejo sitiante, não fosse o fato de este homem ter sido submetido aos mandos e desmandos da política local.

Após ser preso, por questões de demarcação de terra com seu vizinho, Chico Peba, em 1909, e somado à mágoa de não ter visto esclarecido o assassinato do seu irmão, Honório Antunes França, Antônio Dó fugiu da delegacia em que estava preso. Recrutou um grupo de homens que, a partir de então, passou a segui-lo e juntos fizeram "justiça com as próprias mãos”. Durante dezenove anos, Antônio Dó percorreu o Norte de Minas, Sul da Bahia e Sul de Goiás. Fez alguns trabalhos para coronéis da região, trabalhou por conta própria em um 
garimpo na região de Paracatu, mas, jamais voltou a exercer a função de lavrador. Confrontou-se com a Polícia Militar várias vezes, naquele período chamada de Força Pública. O período em que seu bando existiu foi marcado por um excesso de intervenções na administração local por interesses particulares. Os homens que exerciam este poder não limitavam suas ações para conseguir o que queriam, e, consequentemente, "retiravam" ou eliminavam do caminho as pessoas que não estavam de acordo com suas vontades.

Antônio Dó foi assassinado em 1929 por um membro do seu bando que acreditava que seu líder possuía uma garrafa cheia de diamantes. As décadas posteriores à sua morte foram marcadas pelas repercussões de sua história, que tornou-se lenda na cidade de São Francisco e foi contada de várias formas: através de livros, como Sagarana e Grande Sertão Veredas Guimarães Rosa, Antônio Dó: a história verídica de um jagunço famoso - Saul Martins, Antônio Dó: o bandoleiro das barrancas - Manoel Ambrósio e Serrano do Pilão Arcado Petrônio Braz, a música Antônio Dó - Grupo Raízes, Quadrinhas, sendo a Décima de Felão a mais conhecida, a peça teatral Pecado Social, e o filme Antônio Dó, garantindo com essas produções que a história não se perdesse no tempo.

A literatura que existe sobre a vida de Antônio Dó traz consigo uma intensa relação História/Literatura. E esta, por sua vez, contribui para divulgação da imagem da "personagem", além de imortalizar a História. Se o autor tem uma preocupação em salientar os fatos reais, temos na obra a possibilidade de identificar o contexto social do período em questão. Sem entender as relações sociais e políticas do período, não há como entender o que realmente aconteceu com Antônio Dó. No caso das obras de Saul Martins, e Petrônio Braz indagamos: o contexto social aparece nas obras? Tal pergunta nos instiga, uma vez que, o processo histórico em que a vida de Antônio Dó foi alterada, as relações de poder e mandonismo eram baseadas em "favores" e não na legalidade da lei.

Como a obra de Saul Martins foi utilizada como referência para os demais "artistas" que "produziram" arte inspirados nele, procuramos entender qual a metodologia utilizada por Saul para compor o perfil apresentado em sua obra, pois sabemos que este utilizou suas memórias para fazê-la.

\section{A apropriação do Banditismo Social na literatura}

A vida de Antônio Dó foi reescrita várias vezes. As obras literárias de Saul Martins e Petrônio Braz são as maiores divulgadoras deste tema. Vários acontecimentos históricos foram registrados pela literatura, como podemos exemplificar: $O$ Tempo $e$ o Vento 
(VERRISMO, 1979) - relata a formação social do Rio Grande do Sul -, Os Subterrâneos da Liberdade (AMADO, sd.) - revoltas sociais da década de 1950 -, Cavaleiro da Esperança (AMADO: sd.) - relata a vida de Luis Carlos Prestes -, entre outros. A literatura não é somente uma narrativa com "fatos fictícios", mas pode apresentar também informações históricas ou relacionadas a outras áreas do conhecimento (como o caso de Inocência, de Visconde de Taunay, que apresenta informações sobre Biologia). A literatura artística, vamos assim chamar a literatura fantasiosa, apresenta personagens imaginários, situações irreais e fundos morais. Já a literatura que se aproxima de outras ciências, apresenta dados científicos comprovados, personagens "reais" e nem sempre apresentam "um fundo moral". A relação história/literatura é entendida ou definida por Raymond Williams, como: "experiência humana plena, central, imediata", habitualmente com uma referência também a "detalhes (WILLIAMS, 1979, p. 51)",2.

O debate sobre história e literatura não paira somente quanto à intertextualidade, mas também sobre o uso simultâneo de uma fonte entre história e literatura, bem como a validade da literatura como fonte histórica. Tanto a literatura como a história trabalham com apenas uma perspectiva das várias possibilidades interpretativas do evento ${ }^{3}$. Pensando na relação história/literatura, entendemos que ambas se identificam, mas não de forma irresponsável, pois, ambas são controladas pelas fontes, ou pela memória- caso da literatura. A fronteira entre história e literatura torna-se menos densa quando analisamos a metodologia que as compõe. Para Pesavento (PESAVENTO, 1999, p. 820), a obra literária apresenta alguns aspectos que podem conceder a esta uma "verossimilhança" com a obra histórica, sendo que estes aspectos são: presença de personagens psicologicamente reais, provas documentais que comprovem fatos citados, utilização de história oral e referência a vocabulário regional.

Nas obras literárias aqui retratadas, temos personagens psicologicamente reais (Dó, Ribas, Felão, Francilha, Zé Olímpio e Flor Taboca). Há nos textos provas documentais de que fatos citados aconteceram, principalmente no texto de Saul Martins, no qual há recortes de jornais no final do livro. Martins utilizou história oral e o vocabulário regional para escrever a obra, ao inferir na comunidade descrita o folclorista "reconstrói" a linguagem local. Assim, segundo Pesavento, "ambos discursos constroem ideia de realidade" (PESAVENTO, 1999, p.

\footnotetext{
${ }^{2}$ Williams, na obra $O$ Campo e a Cidade, analisa o campo e a cidade através de experiências, sensibilidades, relatos em obras literárias, com significados diferentes e percebe o quanto a temática das poesias produzidas no período mudam a consolidação da Revolução Industrial na Inglaterra.

${ }^{3}$ Mas literatos e historicistas podem vivenciar os acontecimentos da mesma maneira., através das mesmas fontes. Na literatura podem coexistir vários mundos imaginários, mas há apenas um mundo histórico, onde o historiador retira suas conclusões com o auxilio das evidências oferecidas pelas fontes (PESAVENTO, 1999).
} 
830). O que nós faz entender que o contexto social já começa a dar seus primeiros sinais na obra, mas somente estes elementos não são suficientes para concluirmos nossa análise.

As fontes utilizadas pelos escritores para auxiliar na escrita dos textos literários são as mais diversas. Mas dentre elas, as fontes mais utilizadas são os relatos, depoimentos e causos, histórias fantasiosas, lendas. E para que estes registros se tornassem literatura, a História Oral foi imprescindível. A prática de registrar relatos de fatos ocorridos em determinadas regiões e que, de alguma forma, transformaram ou tentaram transformar a "ordem" normal das sociedades, no Brasil, tem na obra "Os Sertões" sua grande expressão. Euclides da Cunha escreveu a obra Os Sertões com olhos de "estrangeiro", de um morador do litoral carioca. Em cada divisão do livro foi feito o perfil de cada parte que compõe o todo da luta (a terra, o homem e a luta). Tema de filme, músicas, análise em artigos, dissertações e teses, é um clássico que representa não só aquele pequeno pedaço de terra no norte da Bahia, mas que reflete a vida de praticamente todo o Brasil, naquele período.

A prática de anotar o que está presenciando e vivenciando é para alguns autores corriqueira. Estes autores, além de expressarem sua vivência, falam do sertão, do regionalismo, das peculiaridades de algumas regiões, do homem sertanejo, de suas crenças, costumes e cotidiano. Escrever sobre o sertão é para alguns autores, o mesmo que preencher páginas de um diário. As fontes de inspiração são muitas: a natureza, as relações sociais, a religiosidade, enfim, o sertão é um infindável celeiro de temas para aqueles que são sensíveis a este universo. O poderio sem controle da elite, a rebeldia de alguns homens ou a força contrária dos bandos armados que atuam conforme a necessidade são registrados na literatura como obras de "denúncia". ${ }^{4}$ As imagens das personagens que são construídas muitas vezes não condizem com a realidade. A identidade de toda uma região, às vezes, é analisada pela ideia que é passada por determinada personagem de algum romance (CHIAPPINI \& BRESCIAN, 2002, p. 163) ${ }^{5}$.

O cangaço, por exemplo, aparece na literatura como registro de uma memória maldita, onde os sujeitos em geral são descritos primeiramente pela sua capacidade de cometer atos violentos a sangue frio, sem aparentar a menor piedade para com sua vítima. Geralmente, somente como pano - de - fundo é que irá aparecer o contexto social, que, na maioria das

\footnotetext{
${ }^{4}$ Utilizaremos a palavra "denúncia" para dizer que o autor utiliza a literatura para expor de forma sutil os mandos desmandos da sociedade em questão.

${ }^{5}$ Outra característica dessa literatura seria, segundo o mesmo autor, a visão lírica da escravidão; cangaceiro, contraposto à modernização e representado como Quixote em luta pela defesa de uma sociabilidade que se perdia; os movimentos messiânicos, transformados em tema regional; o cangaceiro e o coronel tradicionais, apresentados como justos e paternais, embora violentos e terríveis quando tinham seus direitos e sua honra ameaçados e sua confiança traída; o sertão visto como repositório do caráter nacional.
} 
vezes, é o causador da formação da prática do cangaço. Podemos assim, questionar a imagem dos sertanejos, lavradores, cangaceiros, coronéis, líderes religiosos, militares, comerciantes, andarilhos, enfim, todos aqueles personagens que compõem o cenário do sertão:

a partir disto, questiona-se o uso social da literatura como forma de fixação, exposição pública e consagração das representações sociais que ganham o foro de verdades e que, via de regra, são incorporadas pela malha cultural como obviedades. (CHIAPPINI \& BRESCIAN, 2002, p. 190)

Isto nos dá a impressão de que estamos falando de um ser folclórico, lendário, que não existe, ou senão um ser caricaturado e "oposto a cultura popular" o que para Chappini

(...) existe um perverso senso comum que sobrevive inclusive no meio acadêmico brasileiro, que localiza a cultura caipira como "material folclórico", com todo o teor pejorativo que este termo ganhou no contexto nacional, tendo como similar oposto a "cultura popular" (CHIAPPINI \& BRESCIAN, 2002, p. 191),

aproximado do Jeca Tatu escrito por Monteiro Lobato (CHIAPPINI \& BRESCIAN, 2002, p. $203)^{6}$. Este tipo de aproximação anula, sem nenhum critério, todo e qualquer característica das experiências vividas pelo homem no campo, e apresenta e cristaliza atos, estética e memórias como sendo fantasia, exagero ou lendas.

Existe uma dificuldade muito grande em delimitar o que é história e o que é ficção em obras literárias, principalmente em algumas obras escritas após a década de 30 do século XX, período denominado pela literatura de "Segunda Fase do Modernismo" (TUFANO, 1990, p. $68)^{7}$ em que aparecem obras que denunciam os problemas sociais regionalistas de seu tempo. Sobre a literatura produzida neste período, Lígia Chiappini (CHIAPPINI \& BRESCIAN, 2002, p. 163) comenta:

O romance de 30 teria, assim algumas características comuns: o regional seria uma referência para o nacional: a literatura seria uma expressão espontânea da terra e a crítica literária atuaria no sentido "de legitimar a vinculação da produção literária a espaços que seriam "naturais" e fixos, ahistóricos. Ele sabe que as obras são diferentes entre si e é isso o que me interessa, como crítica literária. Mas o que interessa ao historiador é como o grupo foi apresentado e aceitou essa apresentação em bloco para se impor no cenário nacional, na carona de Gilberto Freyre, no que podemos até lhe dar razão. Porém isso não o autoriza a generalizar, entre outras coisas, observações da crítica feitas a Vidas Secas, de Graciliano Ramos, para todas as obras do grupo, quando diz: "A crítica literária passa a explicar até

\footnotetext{
${ }^{6}$ A representação denegridora imputada ao Jeca Tatu mantém-se graças primeiramente à ampla e contínua divulgação nas páginas do almanaque Fontoura, livreto colorido e de fácil leitura produzido e distribuído gratuitamente nas farmácias de todo o país, dos anos 20 até a década de 80 , paralelamente à continua exploração da condição matuta do sertanejo pela mídia.

${ }^{7}$ Período em que as obras literárias apresentavam um grande número de romances que abordavam tanto os problemas sociais nordestinos quanto os urbanos e intimistas psicológicos.
} 
mesmo o estilo dos autores tão áridos, secos. Pontiagudos, lembram o deserto, o cacto.

O sertanejo vive envolto em crendices, misticismo e religiosidade num emaranhado com a opressão, a violência e a miséria. Antônio Cândido percebe que, para entendermos seu mundo, só o faremos com a ajuda de outras ciências:

A atividade artística do homem primitivo e do homem rústico mantém com a vida social e seus fatores básicos ligamentos de tal ordem, que só podem ser bem compreendidos se estudados por meio de combinação de pelo menos três disciplinas - ciência do folclore, sociologia e análise literária (CÂNDIDO, 1975, p. 44).

O estudo da identidade nacional feito a partir de obras literárias permite-nos uma reflexão sobre a nossa história. Assim sendo, o romance histórico foi um dos principais meios encontrados pelos românticos para a interpretação de fatos e personagens de nossa história, numa valorização do passado. Para tanto, contamos com o que esta nos permite. Uma das principais vias de "auto- de -definição da identidade local" está em "Conto sertanejo" que, ao apresentar o amor à terra, externa um ufanismo regional que conduz facilmente o leitor a remeter-se ao ufanismo nacional, proporcionando um sentimento de identidade.

Para Antônio Cândido, a análise sobre a consciência nacional pode ser estudada a partir de registros literários (MOTA, 1980). No caso específico da consciência do sertanejo, existem vários trabalhos literários que desvendam este universo: Graciliano Ramos, Raquel de Queiroz, Euclides da Cunha, Guimarães Rosa e outros. Guimarães Rosa destaca-se dentre os citados por ter escrito textos ricos em detalhes, por explorar a linguagem sertaneja, com base em registros e pesquisas.

Entretanto, a obra literária por isso só não revela sua função histórica. É preciso fazer um exercício de análise, de contextualização, de busca de informações extras, caso contrário ela estará reduzida à função de entretenimento e não de informação ou de formação histórica. Sobre este exercício de análise, Antônio Cândido comenta: "analisar o conteúdo social das obras, geralmente com base em motivos de ordem moral ou política, redundando praticamente em afirmar ou deixar implícito que a arte deve ter um conteúdo deste tipo, e que esta é a medida do seu valor" (CÂNDIDO, 1975, p. 20). Para fazer este exercício de análise, temos as obras de dois folcloristas que escreveram sobre Antônio Dó: Saul Martins e Petrônio Braz.

Tais obras apresentam preocupações que estavam voltadas para o universo rural, e o foco principal está embasado na dificuldade de uma classe social, subjugada a uma estrutura rural, com interferência do poder público na esfera do privado. A prática de registros narrados feitos por folcloristas e memorialistas não é recente. Thompson ao explicar sua trajetória para 
escrever sobre costumes no século XVIII (THOMPSON, 1997), assumiu seu "preconceito" em relação a registros de folcloristas, mas acabou como ele mesmo diz: "À cata de fontes sobre os costumes e suas significações, acabei me voltando para as compilações dos folcloristas" (THOMPSON, 2001, p. 203). No entanto, aqui no Brasil, ainda na década de 1970, Maria Isaura Pereira de Queiroz ao refletir sobre o campesinato brasileiro já afirmava a participação de folcloristas na influência de trabalhos de literatos: "Repeliam assim as evidências que lhes eram trazidas em quantidades por outras fontes- memorialistas, romancistas, folcloristas" (QUEIROZ, 1973, p. 11) e também as narrativas folclóricas ganhavam importância no ato de "descrever" o universo do camponês:

No entanto, quando se passa dos estudos sócio- antropológicos para outros setores das humanidades, a existência dessa população que, no campo, não era nem senhor e nem escravo, não era grande fazendeiro mas também não era trabalhador sem terra, avultada. O caipira, o tabaréu, o caboclo figuravam nas narrativas folclóricas e eram descritos por escritores. (QUEIIROZ, 1973, p. 10-11).

Ambos os folcloristas foram residentes deste universo narrado, daí conclui-se tantos detalhes e precisão na descrição do cenário natural, e a ênfase dispensada ao modo de vida local. E, conforme Raymond Williams nos direciona, temos de ver na literatura rural, não apenas a realidade da comunidade rural, mas a posição do observador nela e em relação a ela, uma posição que faz parte da comunidade que se quer conhecer (WILLIAMS, 1990, p. 229). Saul Martins inserido nesta comunidade em que escreveu, apresentou três posições: na infância era espectador, observador e ouvinte das histórias da vida de Dó. No segundo momento, como militar, era delegado em Januária (local atacado por Dó anteriormente) e no terceiro, repassa para sua obra seus conhecimentos de antropologia. O mesmo aconteceu com Petrônio, que quando criança era espectador, ouvindo os "causos" sobre Dó. Na vida adulta, como ex-prefeito de São Francisco e filho de Brasiliano Braz, escreveu a vida de Dó como homem.

Saul ocupou na sociedade da qual escreveu a função de dirigente da segurança pública e ocupou cargo de administrador. Porém, ambos os escritores recorrem ao fascínio que esta história lhes causava quando crianças. No caso específico da obra de Saul Martins, colhemos um texto literário que aborda a política, a propriedade privada, a violência e as relações sociais da cidade de São Francisco. A abertura ou primeiro capítulo do livro é feita por Saul Martins com o título O bandoleiro (MARTINS, 1967, p. 17) em que é feita uma descrição do homem Antônio Dó. De início, ele já descreve o ódio que corria nas veias deste homem e a violência que ele utilizava para conseguir o que queria: 
O quartel-general de Antônio Dó era o pequeno Arraial de Santo Antônio, ao pé da Serra das Araras, nas primeiras vertentes do Rio Pardo. Sua fama corria. Nas plagas urucuianas todas lhe queriam, por afeição ou medo de suas iras. A Brigada perseguia-o tenazmente, cortando-lhe os atalhos, espreitando-o nos caminhos e encruzilhadas perigosas, buscando-o nas matas e bebedouros certos, nos carrascais, nos trilhos de gado ou assentamentos de morros, identificando-lhe o rastro, caçando-o como se faz à suçuarana comedeira de bezerros. Ele odiava soldado, a quem chamava cachorro-dogovêrno. Empalidecia ao ouvir o nome do Capitão Américo Ferreira Lima e seus lábios arroxeavam, não de medo e sim de raiva, desejo de vingança, ódio concentrado, vontade do ajustar contas com ele, responsável que foi pelo desvio de sua sorte.

Mostra também as mulheres que viveram amancebadas (homem e mulher que vivem juntos sem casar no religioso ou civil, nesta região recebe este nome) com Dó. A primeira, Arcanja (a que era dona do gado roubado por Marcelino, cunhado de Dó e que matou Honório, irmão de Dó), a segunda Margarida, depois Izídia e, por fim, Francilha, que o traiu e ajudou a matá-lo. As paisagens do sertão, seus costumes também são mostrados por Saul Martins:

O homem é xucro e será respeitado se for valente. Ainda hoje, naqueles rincões, o rifle, a faca e o laço são a garantia dos moradores. Recebendo esses ensinamentos e as influências físicas e psicológicas que o lugar e as pessoas lhes poderiam oferecer, três anos lá viveu a família Dó, unida, em paz e esperançosa. (MARTINS, 1967, p. 24)

No capítulo intitulado "Na Estrada do Crime", Saul retorna no tempo e descreve como Antônio Dó tornou-se um homem violento e implacável. Descreve também os acontecimentos desencadeados na prisão e a revolta deste sertanejo. Detalha ainda a arbitrariedade da Força Pública.

-Ah! ... É o valentão? Aqui no município eu não admito negociatas e muito menos desordeiros, entendeu?

-Capitão...

-Cala a boca, atrevido! Você nem casado é. Ainda faço muito em estar lhe dando atenção. Você merece um banho de borracha..

$-? . .$.

-Ė a segunda vez que me incomoda na delegacia. Por que não some daqui?... Responda!

--Capitão, vancê deixa eu spricá pru sinhô! O Marcelino tava robando os gado de Arcanja, o dispois juntou cum Anacreto e mataro meu irmão Honóro...

-qual o quê! Você é um amancebado.

-É de divera, mermo, Capitão, mais nóis vivemo bem e ela respeita. Cuma vancê sabe, corre o diatado qui quem ama cum fé, casado é. Odispois, quaje ninguém sabe qui ela é minha rapariga...

O capitão Américo interrompeu-o:

-não permito, seo sem-vergonha, não aceito que você fale em rapariga aqui na minha presença! Isto é desacato, é faltar com respeito! 
Tudo indica que o oficial forçava uma situação contra o sertanejo. Este, ao insulto, repeliu:

-Vancê é home da lei, mais não pra me dize isso, capitão...

-E por que não atrevido?! Cala a bôca! Sem-vergonha, sim! Descarado...

O Capitão Américo vocifereva ao tempo em que esmurrava a mesa, fazendo cair papéis.

Antônio Dó aproximou-se trêmulo e pálido:

-Severgonha é o senhô!

O Delegado levantou-se, impetuosamente, mas Dó agarrou-o pelo talabarte, dá-lhe um tapa no rosto e derruba-o, em seguida. Não resistindo à agressão, o oficial brada socorro. Dó comprime-lhe a garganta e o obriga a andar de quatro, monta-o e corre-lhe as esporas.

Aparece a ordenança:

-Eu o mato, bandido!

-Mata coisa nenhuma, seo cachorro-do-govêrno! Toma, miserave! (MARTINS, 1967, p. 27-28).

Neste diálogo, observamos a linguagem regional utilizada por Saul, com construção de expressões/gírias e cacoetes ligadas ao Norte de Minas, que acentuam a personalidade dos moradores desta região e criam uma codificação de símbolos que somente as pessoas que habitam esta região sabem interpretar. A formação da identidade pela linguagem, conforme Jô Gandar, dá-se pelo uso que se faz das palavras, num determinado contexto (GONDAR, 2002, p.108).

No capítulo "Declínio", são apresentados os crimes cometido por Dó, e também o papel de "Juiz popular exercido por ele", além de externar a relação povo - Antônio Dó. Assim, o povo percebeu no líder, um homem que, pelo fato de ter se rebelado com a elite local, tinha discernimento do que era bom ou ruim:

Tomando conhecimento da invasão das terras de seu pai, Antonino, filho de João Antônio, auxiliado por um capanga, matou Léo numa estrada. Na ocasião, a cavalo, a vítima puxava a destra um cargueiro, que tinha um menino à garupa. Os assassinos enrolaram a ponta do cabresto no alção da cangalha e viraram o animal e o tocaram, serra abaixo, em sentido contrário, rumo à casa do morto, enquanto o filho chorava, agarrado à retranca para não cair. A esse crime sucederam outros muitos, por vingança.

Bráulio Archanjo de Almeida, irmão de Léo, matou Antonino; João Antônio foi procurar Bráulio e como não o encontrasse destruiu todos os seus bens, ateando fogo à casa e aos campos e exterminando os animais de criação; Bráulio procurou Antônio Dó, em setembro de 1914, e com ele e seu grupo assassinaram João Antônio e roubaram-lhe os haveres.

Foi o primeiro grande erro do bandido, porque a polícia de Paracatu fez causa comum à de São Romão, são Francisco, Januária e Manga.Tempos depois, Dó mete-se noutro caso, impondo sua decisão.

Camilo, esposo de Antônia amigou-se com Praxedes Rodrigues, vulgo Praxedinho e logo foi alvo da cobiça dos Beirão - negros Avelino, Zé Roxo, Eduardo, Camila e Carlota, todos irmãos e que foram, pode-se dizer, criados na fazenda. Alegavam que Antônia lhes devia uns tachos de cobre e outros objetos. Como a viúva negasse a dívida os negros, agora também ligados a 
Simplício do Angical, foram procurar Antônio Dó que, aceitando a proposta, entendeu de julgar o caso.

Que fez? Reuniu o gado no curral e convidou Vicente Batista e Januário Caporra para testemunharem o julgamento e a divisão dos bens da viúva. $\mathrm{O}$ primeiro não aceitou o convite e o segundo, que na ocasião morava a dez léguas dali, dirigiu-se ao local, mas o fazendo sob falsa alegação de que lá ia receber um burro que dera para amansar.

Dó fez a partilha do gado, separando para si mesmo como remuneração, noventa e duas cabeças de criação, sendo vinte e oito vacas, animais de sela e de serviço e bois de carro. (MARTINS, 1967, p. 82).

As práticas sobrenaturais, que são constantes no cotidiano do sertanejo, foram descritas por Saul Martins, como fazedoras do dia-a-dia, e de seu próprio jeito de ser e de se comunicar:

Contam que a viúva, às correrias, enterrara uma lata e um frasco de vidro que continham grande quantidade de jóias e que não mais conseguiu localizar o ponto em que os enterrara.

Casualmente ou por má sorte, Antônio Dó e alguns de seus homens encontraram Januário Caporra em casa de Venço Gobira e ali mesmo o prenderam, ocasião em que foi insultado pelo bandoleiro. Mas, cheio de coragem, repeliu:

-Velho Dó, o réu também tem licença de conversar. E concluiu sentenciando: duas mulheres pariram dois homens neste mundo. Um é o senhor, que é o primeiro sem segundo; o outro é um doido que anda pelo mundo.

A estas palavras enigmáticas, Dó abaixou a cabeça e passou a torcer o bigode. Conduziram-no, amarrado, à sua própria casa, donde fugiu espetacularmente, dizem uns que Januário rezou os bandidos, fazendo-os dormir; outros acreditam que ele teria recomendado a Joana, sua esposa, que temperasse a carne com certas ervas, que teria apontado. Verdade é, que a poder de magia ou de poderoso narcótico vegetal, os bandidos ferraram no sono. Dó não se achava presente porque se reunira ao resto do grupo em Palmital."(MARTINS, 1967, p. 84-85).

Mas a fragilidade perpassa também os homens valentes do sertão. Para o traidor, o melhor momento é aquele em que sua vítima está frágil e distraída. Saul Martins registrou esta fragilidade ao descrever o assassinato de Dó. As ironias da vida: aquele que muitos matou foi assassinado pelos seus, a exemplo de outros homens que tinham o mesmo comportamento como o de Lampião.

Primeiro, abriram-lhe a sepultura, ao pé de uma cagaiteira e em um de cujos galhos pendurararm uma enxada virgem. $\mathrm{O}$ feiticeiro contratado para $\mathrm{o}$ horripilante serviço agia, dava instruções aos sequazes:

-Conde oceis bate na inxada e ela num tini, é esse o dia.

Toda quinta-feira, aos primeiros minutos, faziam a experiência. Afinal, deu certo:

-Óia, disse Fulo à carriola, bati na inxada e ela num tiniu. Foi mermo qui bate numa gamala.

-Apois antonce, mão dento e pé digêro,falou Silvino.

Dito e feito. 
Seguindo as instruções do curandeiro e de Francilha os traidores muniram-se de uma mão-de-pilão, passaram-na ao fogo em forma de cruz e aguardaram o momento decisivo, condiado à Francilha. Na véspera, Antônio Dó chegara de viagem e foi recebido com muita alegria, inclusive por sua mulher. Seu cão lambeu-lhe as mãos, carinhosamente. Dirigindo-se à jagunçada, disselhe Antônio Dó:

-É priciso qui passemo a noite cum as arma na mão. Arguma coisa ta pra acuntecê.

Os malvados entreolharam-se. No dia seguinte, quinta-feira, 14 de novembro, pela manhã, cerca das oito horas, Antônio Dó saiu do quarto acompanhado por Francilha. Estava sem o casaco. Era chegado o momento. Silvino de Jesus tomou da mão-de-pilão e, pela terceira vez, começou a passa-la ao fogo. Disse-lhe Fulô:

-Anda quisso, Silvino. Pisa logo esse café pra nóis isquentá o istambo.

Era uma senha para a comcubina. Antônio Dó achou graça e sorriu ligeiramente. A um pedido de Francilha, agacha-se no canteiro e começa a tirar-lhes uma folhas de agrião. Nesse momento, recebeu ele a primeria borboada. Caiu com a mão no punhal, mas Zé Olímpio, Mane Preto e José Farias usaram as armas contra o chefe. Atiraram tanto que sua roupa se incendiou. Foi Cristina quem abafou o fogo com uma esteira molhada, apagando as chamas. Quatro amigos do bandoleiro, alheios à tradição, correram ás armas mas foram impedidos por Mane Preto. Moeram-lhe a cabeça e o enterraram, em seguida, despido. No bolso do casacão encontraram dois patuás - um Breve de Roma e um Santo Leme, que ficaram para Silvino e José de Farias. Dizem que o sangue brotou da cova. (MARTINS, 1967, p. 96).

A descrição da morte de Antônio Dó, revela-nos a junção de várias vertentes de análise por parte do autor. O caráter "híbrido" da obra de Saul está no fato de tratar-se de um texto com fatos históricos contados em forma de narrativa literária, com elementos da sociologia e antropologia. Em entrevista, Saul Martins relatou que, quando era menino, ouvia os causos sobre Antônio Dó (histórias fantasiosas) contados pelos sertanejos e sitiantes que vinham das fazendas para a cidade de Januária e ficavam alojados embaixo de uma árvore, em frente a sua casa. E, para ele, Antônio Dó era seu herói, seu "herói vingador". Quando era adolescente, com aproximadamente 12 ou 13 anos, Saul teve oportunidade de vê-lo, quando ele estava de passagem pela fazenda da irmã de Saul e alojou ali por algumas horas. Saul relata que observou atentamente tudo que ele fazia e crê que Antônio Dó deve ter percebido sua presença, pois o futuro escritor não conseguia retirar os olhos do seu herói.

Mais do que fazer uma obra literária, o objetivo dele era imortalizar a história de Antônio Dó, e também relatar a má administração da justiça, mostrar os desvios de comportamento da corporação a qual o próprio Saul pertencia. Mas quando lhe perguntamos o que ele pensava sobre Antônio Dó, respondeu: "Foi um rebelado, ele foi coagido pela má administração da justiça” (MARTINS, 1967, p. 96). 
Quando Saul era menino, encantado com as histórias a respeito de Antônio, escrevia em cadernos os relatos que ouvia, e assim começou a registrá-los. Após alguns anos, já militar, pesquisou nos Arquivos da Polícia Militar a respeito do personagem. Não satisfeito, partiu para a pesquisa em jornais do acervo da Hemeroteca de Belo Horizonte e, por fim, retornou à região de Januária e São Francisco, onde passou a recolher relatos, porém, desta vez, tendo o cuidado de ouvir várias pessoas sobre o mesmo fato, para posteriormente compará-lo e considerar "verdadeiro" somente aquele mencionado no mínimo três vezes.

A obra foi editada em 1967 pela primeira vez e consagrou-se vencedora do $5^{\circ}$ Concurso de Monografias sobre o Folclore Nacional. No desenrolar da trama, o folclorista descreve a vida de Antônio Dó e de seus homens, considerando o cotidiano do sertanejo, sua linguagem e seus costumes. No prefácio da $1^{\text {a }}$ Edição, Saul explica quais as metodologias que utilizou para escrever a obra. Expõe sua relação com a Polícia Militar, fazendo um breve comentário sobre o que entende ser científico e ficcional em seu livro:

A história é verídica e a escrevemos com todo rigor científico. Se houver acréscimo, estes são oriundos da fantasia ingênua do sertanejo e não de quem os anotou. Aliás, não é fato novo: o povo cria lendas em torno de personagens reais, heróis sofredores ou vingadores com os quais muitas vezes se identifica. E é assim que se vai formando a tradição e todo o acervo cultural de uma simples comunidade ou de uma pátria imensa (MARTINS, 1967, p. 1).

A segunda edição é datada de 1979 e conta com algumas alterações em relação à primeira. No prefácio da segunda edição, Saul inicia seu texto comentando o filme do Cineasta Paulo Leite Soares, além de citações de outras obras literárias que falam sobre Antônio Dó. Mas, segundo o próprio folclorista, é a terceira edição que "está mais próxima da

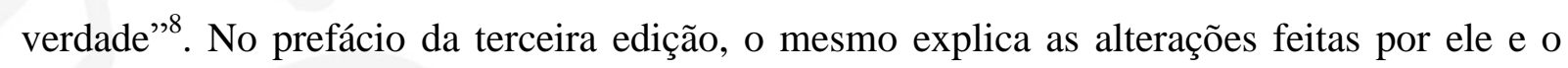
acréscimo da vida de Rotílio Manduca, feito através de uma entrevista com a filha dele, um fazendeiro da região de São Francisco, que ficou conhecido pelos atos de violência que cometeu.

\footnotetext{
${ }^{8}$ Entrevista com Saul Martins em 14/11/2002. Duração de duas horas.
} 


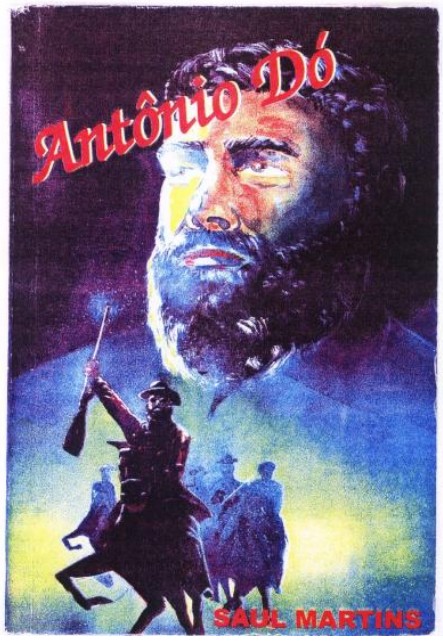

Foto 1. Capa do Livro de Saul Martins. Fonte: imagem do acervo pessoal da autora.

Alguns dos fatos novos que contribuíram para que Saul Martins "atualizasse" sua obra foi um diálogo travado entre ele e o senhor Antônio Marcondes (escrivão do cartório da cidade de São Francisco, de 1951 a 1982). O diálogo se deu através de cartas, durante o período de preparação do segundo livro (o primeiro já havia sido publicado e o segundo estava "recém-lançado"), o qual revela que algumas informações, que até então estavam obscuras, apresentam características sobre Antônio Dó, possibilitando uma falsa impressão sobre o mesmo. A primeira edição do livro retrata a pessoa do Antônio Dó como um lavrador rude ligado à terra (MARTINS, 1967, p. 23-27). O fato de um homem ser alfabetizado ou não durante a primeira república fazia diferença, pois a chance de ser alfabetizado era um privilégio de poucos, o que nos fez concluir que a família de Dó possuía posses e não era ele um homem sem conhecimento nenhum e daí o motivo pelo qual não aceitou o que estava acontecendo com ele. Após a "descoberta" deste fato, o personagem recebeu outra descrição, na terceira edição, depois do equívoco ser desfeito através da carta:

Desejo desfazer um pequeno equívoco de sua nota $n^{\circ} 32$, às fls. 146, quando diz, entre parênteses, que o documento original esta em meu poder. Esteve, sim, quando mais ou menos em 1970, substituí, por um ano, o titular do cartório do crime, sr. Afrânio Couto Paixão, hoje meu compadre e que ainda exerce dito cargo, estando, pois, o original, em poder dele. Por sinal, o processo do qual extrair ou fotocopiei aquele auto, ainda existe e pode ser manuseado por quem o desejar. Se não lhe fosse muito incômodo eu até o convidaria para vir aqui pesquisa-lo. Quem sabe o amigo com a capacidade de dedução que tem, não encontraria nele algum subsídio para esclarecer alguma dúvida por acaso existente sobre este ou aquele aspecto da vida do Dó? O que eu disse sobre este apelido não passa, talvez, de invencionice de pessoa que procurou o caminho mais curto para satisfazer minha curiosidade infantil. Mas, de qualquer forma, aquele auto nos deixa cépticos, vez que, nem o réu nem a autoridade cuidaram de por em relevo o pequenino topônio. Lembro-me bem que minha vò me repreendia, secamente, quando tratava 
alguém pelo apelido. Quem sabe se o tio-avô não tinha este mesmo escrúpulo? A resposta pode está no bojo daqueles velhos autos. ${ }^{9}$

A data da morte do irmão de Antônio Dó, Honório França, também foi questionada por Antônio Marcondes e motivo de debate entre os dois, o que levou a fazer uma correção de uma edição para outra.

Conforta-me muito saber que pude colaborar numa obra tão grandiosa quanto esta sua segunda edição do "Antônio Dó". E vou me esforçar para the responder aquela indagação sobre a data exata da morte do Honório, dentro dos próximos dias, pois com a chegada do novo Juiz de Direitos para a comarca, não tem sobrado tempo, tal a monta de serviços atrasados. Mas o assunto da enchente me obriga a vir a sua presença antes daquela resposta, se é que me vai ser possível responde - la, documentadamente, pois se escrevi que o Dó recebeu, preso, a notícia da morte de seu pacato irmão, foi lembrando a explicação de minha vó para justificar a revolta do Dó contra tudo e contra todos - correto e prestimoso que era, antes, em suas ações e em seus negócios. Aquele processo me parece que nada tem a ver com aquela morte e, na distribuição não consta nada que as autoridades processassem o autor daquele homicídio, ardilosamente, praticado $^{10}$.

A falta de circulação do livro na região de São Francisco dificultou o conhecimento da história de Antônio Dó. Antônio Marcondes comenta ainda que ficou sabendo da propagação do livro, que não chegou a São Francisco, pelo hábito diário que tinha de ler os principais jornais da região. O relato abaixo confirma como ele ficou sabendo da existência do livro:

Meu caro Saul, não tome por base de cálculo para avaliação da circulação do seu livro, pelo fato de eu não ter lido ainda. Eu estou mesmo por fora do movimento literário. Imagina só que não conheço nenhuma obra dos escritores mencionados na sua carta, se bem que os conheço de nome. A pobreza não é de seu livro, mas exclusivamente minha. Não me pesa dizerlhe que o tenho lido se restringe mais a publicações em jornais e, às vezes, em revistas. E como me espantei em saber que você é um escritor consumado, com 17 obras publicadas! E destas 17, duas nos tocam de perto: Antônio Dó e os Barranqueiros, cuja leitura também ainda não fiz. ${ }^{11}$

Para Saul, o filme ${ }^{12}$ teria sido de melhor qualidade se tivesse sido assessorado por alguém que "conheceu" a história.

Recebi hoje sua carta. A pressa em responder a ela hoje mesmo basta para demonstrar sua importância. Cria-me, realmente não fiz mau juízo de pessoa alguma. Pensei, sim., e você o confirmou: o meu pobre livro pouco circulou, não teve distribuição editorial. $\mathrm{O}$ artigo meu publicado pelo Estado de Minas de 09 deste mês foi escrito com o fim único de colocar os pingos nos ii e atrair a atenção de alguém para o pioneirismo e honestidade de minha

\footnotetext{
${ }^{9}$ Carta enviada por Antônio Marcondes a Saul Martins em 15 de dezembro de 1979.

${ }^{10}$ Carta de Antônio Marcondes a Saul Martins em 24 de fevereiro de 1979.

${ }^{11}$ Carta de Antônio Marcondes a Saul Martins em 31 de janeiro de 1979.

${ }^{12}$ No final da década de 80 foi filmado um roteiro sobre a vida de Antônio Dó, porém não foi possível localizalo. Saul Martins teve oportunidade de assisti-lo e por isso fez este comentário.
} 
pesquisa. Conforme leu, minha obra resultou de muitos anos de esforços. Embora publicado há 12 anos, foi escrita de fato em 1947, isto é, 18 anos antes de sua publicação. Há muitas falhas, sobretudo na apresentação, vale dizer, defeitos de forma. Mas, há também, pequenos defeitos de conteúdo, os quais não chegam a comprometer a obra. Em vista disso, estou com a $2^{\mathrm{a}}$ edição preparada, agora atrás de uma editora. A $2^{\mathrm{a}}$ edição, sim, está refundida, corrigida e aumentada. Nesses doze anos, a contar da publicação do livro, em 1967, recebi dezenas de cartas, quase cem. Tais cartas e algumas entrevistas posteriores (Arinos, Montes Claros, São Romão, Formosa-GO, etc.) me capacitando a uma aproximação muito maior da verdadeira realidade. Posso garantir a você que a $2^{\mathrm{a}}$ edição será $95 \%$ da realidade Antônio Dó, de 1910 a 1929.

Infelizmente, o produtor do filme - Paulo Leite Soares, não me convidou para assessorá-lo. Pedi muito que fizesse umas tomadas (ao menos isso) do ambiente fisiográfico regional: o Rio Catarina, o arraial da Serra, a Serra das Araras (de linda coloração vermelha), que ficaria magnífico em um filme a cores. Não sei se me atendeu. Acho que o filme vai fugir muito da realidade. É uma pena! Seja como for, alguma coisa positiva há de ficar, sem dúvida. Em geral, o roteiro não acompanha linearmente a vida da personagem. Isto não acontece apenas no cinema. Sucede o mesmo na pintura, na literatura, na música e em todas as artes. Veja, por exemplo, Guimarães Rosa; o sertão, as nossas veredas, o estilo de vida do morador do norte de Minas, região do Vale do Rio de São Francisco são meros pontos enfocados pela genial inspiração do artista. O mesmo poderíamos dizer de Mário Palmério, Jorge Amado, Heitor dos Prazeres, Djanira, Villas Lobos, Arianos Suassuna, Catulo, Juvenal Galeano e outros, em que o material popular serve tão somente de motivo ou de ponto de partida.

Claro, os aspectos negativos do filme Antônio Dó seriam minimizados se o produtor tivesse a assessoria de alguém com conhecimento seguro de evento e das paisagens, dos costumes de nossos irmãos barranqueiros. Enviei o livro para você, pelo Correio, amanhã eu depois. Mas, preferia que você não lesse, apenas o guardasse. Acho que vale a pena esperar a $2^{\mathrm{a}}$ edição. Você está citado á p. 18 de novo original. Peço-lhe o favor, caso você julgue possível, uma cópia do auto de qualificação. Serviria, e muito, para confronto. Ao pé do auto, os dados relativos á fonte (livro, folhas, cartórios, data, etc.), tudo que for necessário á identificação do documento ${ }^{13}$

A obra de Saul Martins foi utilizada como fundamentação histórica para a professora Socorro, no período em que a mesma formulava o texto da Peça Teatral intitulada "Pecado Social”, encenada em 1995 na cidade de São Francisco. O juiz Petrônio Braz ${ }^{14}$, que também escreveu sobre Antônio Dó, utilizou a obra de Saul Martins como parâmetro para seu trabalho.

O próprio Saul comentou sua obra em uma reportagem feita para o jornal Estado de Minas em 1979, no qual o folclorista explicou o que ele entende ser folclore na história e também no seu texto, e o significado do misticismo para o sertanejo, confirmando o que

\footnotetext{
${ }^{13}$ Carta de Saul Martins para Antônio Marcondes em 19 de janeiro de 1979. Os grifos constam na carta original.

${ }^{14}$ Juiz, ex-professor de Direito da Universidade Estadual de Montes Claros e filho de Brasiliano Braz autor do livro São Francisco nos caminhos da História.
} 
escrevera ser folclore no seu livro: Folclore - Teoria e Método (MARTINS, 1986, p. 14). O comentário abaixo feito por Saul demonstra para nós ser ele uma autoridade no assunto:

O meu livro Antônio Dó vai sair em segunda edição, pela Interlivros, alinhado na seção de cultura popular desta conceituada editora. Achamos validada e muito nos alegra a colocação, porque de fato a obra contém observações de caráter folclórico bastante variadas. Sem falar nos aspectos dialetológicos que lhe respingam todas as páginas e se condensam no glossário final, registram-se crendices e elementos mágicos para fazer e anular malefícios, abrir ou fechar o corpo das pessoas e descobrir criminosos; hábitos, práticas, usos e costumes do povo; dias aziagos que pressagiam desgraças; culinária, trajes típicos e outras manifestações ergológicas, sobretudo ligadas a pastoreiro, iluminação, ervas soníferas, medicina caseira, farinhada e ocupações domésticas; lendas, provérbios, vaticínios, meteorologia empírica, denominação tradicional de partidos políticos, alcunhas e cor de animais. Entre as pessoas do lugar, difundia-se a crença, bastante vulgarizada, segundo a qual Antônio Dó adivinhava, era portador de qualidades sobrenaturais, sabia ler o pensamento de quem the desejasse mal. Em vários momentos de sua vida atribulada, revelou essa faculdade extraordinária de vislumbrar o futuro, por exemplo à véspera de sua morte: -Precisamos passar a noite com as armas na mão, que alguma coisa ruim está para acontecer! ${ }^{15}$

Ao comentar a Décima de Felão, quadrinha muito cantada em São Francisco, Saul só não entra em detalhes para explicar como os "costumes" se tornam tradição (THOMPSON, 1997). Faltou ao professor analisar esta prática de repetição por várias pessoas que estabelecem a formação dos costumes. No caso, o costume de cantar esta quadrinha tornou-se tradição na cidade de São Francisco.

Como reza a lenda, Felão morreu comido por carrapato caiano, cuja correição se deveu a reza braba de Galdino, uma de suas vítimas. O antigo sítio do Oficial, em Corinto, é hoje mal-assombrado. Diz o povo que sua alma ali aparece, a dez horas, montada em uma besta reta. Em vida, Sua maldade foi preservada em décima, que a tradição conserva no Vale do Rio de São Francisco. O estribilho é assim: Felão vei? / Não vei, não! / Por que não vei? / Não sei, não!

$\mathrm{O}$ apelido com que o bandoleiro se tornou conhecido e famoso resultara de sentimento afetivo da comunidade, cujos membros referiam-se a ele sempre com pena: "tenho dó de seo Antônio!". Da repetição do substantivo, fixou-se o antropônio Antônio Dó.

As práticas de simbolismo nesta região eram e ainda são muito intensas, principalmente no tocante a rituais funerários. Saul comenta como o irmão de Dó foi enterrado e como o povo descreveu esta prática:

Segundo a lembrança coletiva, o corpo de Honório, irmão de Dó, foi sepultado de bruços, tendo na língua uma moeda de prata, simpatias que impedem a fuga do criminoso. Tal prática era comum no Brasil, sendo que

${ }^{15}$ ESTADO DE MINAS, sábado 8 de setembro de 1979. p. 5. Grifos meus. 
vários autores a ela se referem em suas obras. (Estado de Minas, 08/09/1979, p. 5)

A repercussão da obra de Saul Martins foi grande, principalmente através dos jornais que divulgaram algumas matérias comentando o livro. Em 1977, Zulmira Rolim ${ }^{16}$ divulgou nota, intitulada "Antônio Dó, o jagunço de São Francisco", comentando o quanto para ela a história de Antônio Dó era ambígua.

A surpresa foi enorme. Eis que a foto não revela, o rosto de um fascínora, mas estampava as feições nobres de um respeitável coronel das barrancas. O olhar triste não desafiava leis nem homens, era um olhar de gente mansa, dessas gentes que se acostumaram com a insensatez, humana e já não esperam nem desesperam, não compreendem nem deixam de compreender.

Antônio Dó virou lenda enquanto vivo. Os pobres ajudavam, os ricos o protegiam, o sertão agreste o escondia e o alimentava e o fio do telégrafo, desesperado, tilintava as calamitosas notícias dos horrendos feitos do jagunço barranquês.

As mães temiam, as crianças ficaram trancadas, todas se protegiam, menos as donzelas virgens que Antônio Dó exigia, dos seus homens, um respeito místico e supersticioso pela honra das donzelas sertanejas. Tudo que sei sobre Antônio Dó, li no livro do etnólogo Saul Martins, professor de antropologia da UFMG, ele próprio barranqueiro e membro da mesma Força Pública que sustentou a luta sangrenta contra os jagunços, anos a fio.E quem quiser saber mais, que pegue o livro e o leia que não serei eu a fazer o leitor com lembranças tão dolorosas. Felão morre comido por tudo quanto é bicho ruim. Morte pavorosa, devorado vivo e aos poucos. Está aí Saul Martins que não me deixa mentir. Uma história e tanto, que já tendo encontrado seu cientista social, aguarda seu dramaturgo, seu poeta, seu romancista. Antônio Dó possuiu uma força carismática que dá pra encher um palco, as folhas de um romance, e cabe até na pena de um poeta. Mais do que um jagunço, foi um injustiçado, metido no cangaço, à força da justiça da época que tanto pancada lhe deu que o pacato homem se cansou e virou bandido. (Estado de Minas, 05/04/1977).

Não só o livro mereceu destaque pela imprensa, mas o tema em si. Em outra reportagem, Dó é visto como símbolo de resistência e chega a ser comparado com outros "heróis" ou "mitos", entre eles, Lampião:

Com efeito o livro lembra mais um roteiro cinematográfico, não obstante ser uma bem documentada pesquisa histórico-sociológica, de sabor folclórico. Belo tema para o cinema mineiro! As peripércias desse mini-guevara não faltou nem mesmo o ingrediente novelesco da traição da amada calculadamente seduzida em darem uma garrafa de jóias ciumentamente guardada pelo chefe amante, e as chicotadas com que a Dalila ou que tem nesta sertaneja foi castigada, ao reclamar o amor de José Olímpio e o preço. (AMARAL, Estado de Minas, 12/10/1978).

Ambas as reportagens comentam que esta história deveria tornar-se um roteiro de filme ou um roteiro teatral. Entendem que é um tema propício para a transformação em

\footnotetext{
${ }^{16}$ Convidada pelo jornal Estado de Minas para comentar a obra de Saul Martins.
} 
manifestação artística. Ao fazer a leitura desta obra, o impacto da trama descrita gera no leitor um sentimento de raiva e ou de curiosidade. A recepção se dá de forma bastante diferenciada. A professora Liriana Guimarães revelou em entrevista que achou a narrativa interessante, e o que mais chamou sua atenção foi a rápida mudança de personalidade, causada pelo meio social, além da descrição acentuada das práticas características do coronelismo, dinheiro e poder, justiça para quem tinha dinheiro. Para Liriana Guimarães, a associação da história de Antônio Dó com a de Lampião foi imediata, e que a personalidade de baiano foi adaptada ao jeito mineiro de ser.

A relação História e Literatura, em torno da história de Antônio Dó, não ficou somente na literatura regional. Os textos de expressão nacional e mundial também têm registrado o nome Antônio Dó. Guimarães Rosa, ao descrever o sertão norte-mineiro, faz referência a este rebelado em alguns de seus romances: "Sagarana", "Grande Sertão Veredas" e outros. A obra de arte e a literatura em especial têm uma característica de refletir sua época, seu meio de produção e inspiração. Esta característica será marcante nas obras produzidas no período de 1930 a 1945:

Após a fase de consolidação, 1930 a 1945, reunindo a literatura de caráter regionalista, surge uma nova geração de escritores brasileiros, aquela que seria chamada de universalista, a geração de 1945. Trouxe para a ficção nacional um carácter experimental, usando recursos lúdicos para aprimorar o romance brasileiro.

Podemos notar nesta nova geração algumas tendências básicas: a permanência do testemunho, a atração pelo transreal numa tentativa de justificar a condição humana por sua projeção no mundo mítico da arte, a redescoberta da linguagem, como um elemento de comunicação e gerador da realidade. A realidade aparece como fonte de inspiração para os autores, sejam eles testemunhas ou não daquela realidade. O testemunho é para estes escritores o mediador entre realidade e narração. Assim explica Bressiani:

\begin{abstract}
A verdadeira mímese deve ser procurada nas obras de arte menos preocupadas em refletir sua época. (...) é justamente quando uma obra rompe com essa espécie de verossimilhanças que ela desenvolve sua verdadeira função minética (CHIAPPINI \& BRESCIAN, 2002, p. 239).
\end{abstract}

A representação do real através de símbolos dá-se pela revolução formal e estilística, ou seja, a experiência humana é reproduzida na literatura em forma de estilos literários, e ao estilo rosiano de escrever, os literatos classificaram como pós-modernista (BOSI, 1972). Saul Martins comentou em 1979, numa reportagem para o jornal Estado de Minas, como Rosa percebia ser Antônio Dó e em quais obras ele era mencionado: 
O romancista João Guimarães Rosa cresceu o nome de Antônio Dó, registrando-e em suas obras: na SAGARANA - Livraria José Olympio Editora - 5 edição - Rio de Janeiro, 1958, pp. 363 e 364: “...maior do que Antônio Dó ou Indalécio; o arranca-tôco, o treme-trema, o come-brasa, o pega-à-unha, o fecha-treta, o tira-pro-as, o parte-ferro, o rompe-e arrasa: seu Joãozinho Bem-bem". No GRANDE SERTÃO: VEREDAS - livraria José Olympio Editora - $4^{\mathrm{a}}$ edição - Rio de Janeiro, 1965, Antônio Dó é citado às pp. $16,18,66,128$ e 129 . O registro da p. 128 tem a marca de seu estilo único: " na era de 96, nestes derradeiros anos, quando Andalécio e Antônio Dó forcejaram por entrar lá, a cavalo, o povo de São Francisco se reuniram e deram fogo de defesa (MARTINS, 1979).

Outro folclorista que registrou a vida de Antônio Dó, com base na literatura de Saul Martins, foi Petrônio Braz ${ }^{17}$. Engajado à 'tradição oral' da sua cidade natal, e indignado com “comentários equivocados" sobre Antônio Dó, Petrônio Braz escreveu um livro sobre tal personagem. A obra comenta a vida de Dó e sua família, desde a saída dos mesmos de Pilão Arcado, na Bahia, em 1878, até o assassinato dele em 1929. A vida intima de Antônio Dó é registrada também, o que não é feito por Rosa e Martins. A ênfase maior no livro é a personalidade de Dó, mas o cenário político e todas as desavenças que ocorreram no período em questão também são relatadas.

Em entrevista, Petrônio Braz comenta por que escreveu sobre a vida de Antônio Dó:

Na minha juventude eu sempre ouvia, nas conversas ao pé do fogo, de um dos ex-jagunços de Antônio Dó, que foi armeiro do meu pai. Isto nos anos de 1937, 1938 (eu era menino), fazia os primeiros anos de primário. A gente ouvia dessas pessoas os fatos, as histórias. E o povo em geral tinha uma certa veneração por Antônio Dó. ${ }^{18}$

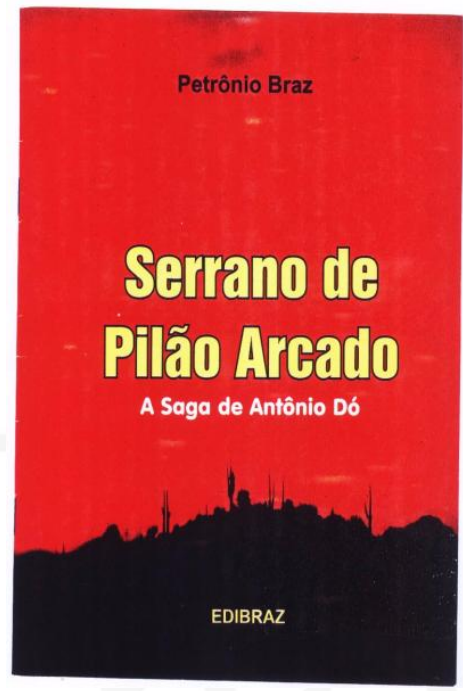

Foto 2. Capa do livro de Petrônio Braz. Fonte: imagem do acervo pessoal da autora.

${ }^{17}$ O livro Serrano do Pilão Arcado ainda não foi lançado, porém o autor gentilmente cedeu uma cópia para nossa apreciação.

${ }^{18}$ Entrevista concedida em 28 de dezembro de 2002. 
As histórias de Dó têm para cada autor um motivo diferente para ser escrito. Para Petrônio, o objetivo principal de escrever sobre Dó era "Para registrar não somente a versão da polícia ou dos coronéis da cidade sua intenção registrar o "homem Antônio Dó”. Pois ele entende que "Antônio Dó, foi uma vítima da opressão da política que imperava no final do século XIX." Para produzir a obra que daria ênfase ao "homem Antônio Dó', Petrônio Braz comenta: "para escrever eu retornei à cidade em que ele nasceu (Pilão Arcado - Bahia) e procurei refazer o percurso feito pela família”.

Na introdução da obra, Petrônio Braz a apresenta e faz a sua descrição sobre Dó:

... conta de forma romanceada, a vida de Antônio Dó, o chefe de jagunço contra o qual o governo se cansou de mandar expedições que voltavam sempre derrotadas e, se facilitassem, sem o comandante. Dó, que antes de ser jagunço era um humilde camponês, não permitiu nenhuma vitória às forças policiais que o perseguiram. (BRAZ, s.d, p. 11)

Sobre o livro, o autor comenta:

Mas o livro não é só a história de Antônio Dó, que foi um menino da fazenda Salitre, em Pilão Arcado; um fazendeiro em São Francisco; um garimpeiro no Rio Claro; um jagunço com fama desde o Carinhanha até o Gerais de São Felipe; um bandoleiro que as forças do governo acabaram por desistir de querer matar. Serrano de Pilão Arcado mostra com muita clareza as arrelias políticas da cidade de São Francisco, com os líderes locais tramando conspirações para se agarrar ao poder, com assassinatos, deportações, incêndios, cárcere privado, canalhice, nobreza de caráter, grandeza de espírito, tudo o que há na vida e, por conseguinte, há no romance. (BRAZ: s.d,)

O autor, por ter nascido nesta região e conhecer bastante o jeito de ser do sertanejo, não deixou de registrar em sua obra as tradições dos seus conterrâneos: O vale do São Francisco, onde ocorreram tantas façanhas heróicas, está a reclamar de seus filhos, que tenham algum pendor pelas letras, que façam conhecidos esses feitos e mostrem os seus usos, costumes e tradições (BRAZ, s.d, p. 13).

Para o escritor, é inevitável fazer a pergunta que muitos fazem até hoje: "Busquei, com minhas limitações, responder a um questionamento: Foi Antônio Dó um bandido? (BRAZ: s.d, p. 13) Também para ele, definir quem realmente foi Antônio Dó, é muito difícil. Porém, na sua memória uma afirmativa é clara - "Antônio Dó era herói”:

Este livro é fruto do meu apego às coisas ribeirinhas do Rio São Francisco. Nele tento resgatar a imagem do herói sertanejo, sem me esquecer do bandido que se ocultou em algumas de suas ações. O jagunço - afirmou Urbino Viana - não era nem herói nem bandido, ao mesmo tempo nos parece ambas as coisas. (BRAZ, s.d, p.13) 
A metodologia utilizada por Petrônio Braz é descrita por ele na introdução da obra, mostrando que a mesma é uma união de outros trabalhos, onde são retratadas personagens reais e fictícios:

Procurei um nexo entre a realidade - narrada por Saul Martins, do ponto de vista da Polícia Militar e por Brasiliano Braz, sob o aspecto político - e a ficção literária, escrita por Manoel Ambrósio, procurando, desse modo, reescrever a vida de um homem lendário, retirando a aridez dos fatos históricos (...). Todos os personagens desta história são reais... (BRAZ, s.d., p. 13-14)

O contexto sociocultural para ele não pode deixar de ser relatado:

Que a leitura traga também um melhor conhecimento dos usos e dos costumes do sertão são -franciscano, seu falar regional, ou que sirva, na afirmação de José de Alencar, para desenfastiar o espírito das coisas graves. (...). Este livro é produto de minha sensibilidade emotiva, do meu apego às coisas e às tradições do Rio São Francisco, mas não sei se, por meio dele, vou perfazer o circuito comunicativo que me levará ao leitor... (BRAZ, s.d., p. 14-15)

Descrição feita por pelo autor sobre o personagem, ou, pelo menos como Petrônio imaginava ser fisicamente Antônio Dó: Antônio com seus dezoito anos, (...). Sua pele morena, queimada pelo sol, os ombros e o peito salientes, lábios grossos, cabelos pretos e encarapinhados. (...) Mostrava uma marcante personalidade. (BRAZ, s.d., p. 22). O modo de arrumar já demonstrava sua identificação com o cangaço: “O chapéu - de - couro, seu orgulho particular, (...) com aba inteiriça dobrada na frente à moda dos cangaceiros” (BRAZ, s.d. p. 23).

Na sua personalidade: "Teimoso, de poucas palavras, obstinado" (BRAZ, s.d., p. 23), já demonstrava que Antônio Dó era homem de lutar pelo que queria. $\mathrm{O}$ autor remete à história de Canudos, mencionando Antônio Conselheiro no texto:

Pai de Antônio Dó, sentindo-se indeciso sem saber para onde iria habitar com sua família... "sentindo-se incapaz de solucionar sozinho os problemas que o afligiam, chegou a pensar em procurar Antônio Conselheiro que sabia, por notícia certa, ter estado em Chorrochó, Monte Santo, Curaçá, Tucano e outras localidades não muito distantes." (BRAZ, s.d., p. 40)

Percebemos que a construção de uma obra literária dá-se por etapas, Saul e Petrônio, com lembranças da infância ou memórias. A produção de uma obra literária que apresenta conhecimento histórico não é aleatória. Sempre há um ponto em comum entre a vida pessoal do autor e a obra em si. E o resultado da mesma depende da metodologia escolhida pelo autor, e de como ele irá organizar as "fontes" que possui. A literatura "produz" o imaginário, à 
medida que o autor cria um perfil do seu personagem e o leitor assimila para si estas características.

Os folclorista que escreveram obras literárias sobre Antônio Dó, compuseram um perfil próprio e escreveram com base em uma paixão. E todos os que conhecem o sertão do norte de Minas ou vivem nele, podem, através da escrita destes, identificar objetos de inspiração do próprio sertão, como: clamar o povo à luta como, seja para que os norte mineiros saibam que às margens do São Francisco viveu um "herói", como disse Saul, ou mesmo para que não contem mais a história de forma "errada", conforme a indignação de Petrônio.

\section{Considerações finais}

Concluindo nosso debate, percebemos que o contexto social aparece na obra de Saul Martins, e, esta obra foi inspiração para todos que "produziram" sobre Antônio Dó. Apenas a professora Socorro, dentre os entrevistados, utilizou, como base principal de pesquisa, Brasiliano Braz. E que há um traço comum entre os escritores. Todos colocaram a resistência e perseverança, em relação à condição de subordinados a um sistema que não concordavam e às dificuldades naturais do cotidiano do sertanejo. Saul, mesmo tendo escrito sobre a Força Pública e tendo sido um membro da mesma, não deixou de demonstrar que o sertanejo não é facilmente dominado e que, de uma forma ou de outra, lutava pelo que queria. Compreendemos que, tanto Saul como Petrônio, escreveram com o objetivo de que as pessoas entendam Antônio Dó como um "salvador do sertão", aquele que veio para resolver os problemas e injustiças.

Para Saul, um "herói”, para Petrônio, um "camponês que se tornou jagunço”. E nas obras aparecem não só as relações sociais como as práticas de violência da polícia e o mandonismo político. A partir do momento em que os folcloristas e compositores escreveram procurando verificar se os fatos que estavam relatando aconteceram ou não, eles contribuíram para que o público formulasse uma ideia de quem foi Antônio Dó. Esta ideia, por sua vez, somada a outras informações, formam a imagem que várias pessoas têm, e este é o imaginário social. Além de entenderem as relações sociais e o contexto em que os acontecimentos se deram e como décadas posteriores os registraram. 


\section{Referências bibliográficas}

AMADO, Jorge. Os subterrâneos da liberdade. $11^{a}$ ed. São Paulo: Circulo do Livro, s.d.. AMADO, Jorge. Cavaleiro da Esperança. $15^{\text {a }}$ ed. São Paulo: Circulo do Livro, s.d... AMARAL, José Altino de. Estado De Minas, Quinta-feira, 12 de outubro de 1978.

BOSI, Alfredo. História Concisa da Literatura Brasileira. $2^{\mathrm{a}}$ edição. São Paulo: Ed. Cultrix, 1972.

BRAZ, Petrônio. Serrano de Pilão Arcado: a saga de Antônio Dó. Mimeografado. CÂNDIDO, Antônio. Literatura e Sociedade. $4^{\mathrm{a}}$ ed. São Paulo: Editora Nacional, 1975.

CERTEAU, Michael de. A invenção do cotidiano. 1. Artes de fazer. $7^{\mathrm{a}}$ ed. Petrópolis: Vozes, 1994.

CHIAPPINI, Lígia \& BRESCIANI, Maria Stella (org.). Literatura e Cultura no Brasil: identidade e fronteira. São Paulo: Cortez, 2002.

FERREIRA, Lucia M. A.. Linguagem, identidade e memória social: novas fronteiras, novas articulações. Rio de Janeiro: DP\&A, 2002.

LINS, Zulmira Rolim de Mendonça. Estado De Minas, terça-feira 5 de abril de 1977.

MARTINS, Saul. Antônio Dó - A história verídica de um jagunço famoso. Belo Horizonte: Imprensa Oficial. 1967.

MARTINS, Saul. Estado De Minas, sábado 8 de setembro de 1979.

MARTINS, Saul. Estado De Minas, 09 de janeiro de 1979.

MARTINS, Saul. Folclore: Teoria e Método. Belo: Horizonte, 1986.

PESAVENTO, Sandra J. Fronteiras da ficção: Diálogo da História com a Literatura. In: NODARI, Eunice. (org.) História: Fronteiras. São Paulo: Humanitas/FFLCH/ USP: ANPUH. 1999.

QUEIIROZ, Maria Isaura P. de. O campesinato Brasileiro. São Paulo: Vozes, 1973.

THOMPSON, E. P. Costumes em comum - estudos sobre a cultura popular tradicional. São Paulo: Cia das Letras, 1997.

THOMPSON, E. P. Folclore, Antropologia e História Social. In: As peculiaridades dos Ingleses e outros artigos. Campinas: UNICAMP, 2001.

TUFANO, Douglas. Estudos de língua e literatura. 4a ed. São Paulo: Moderna, 1990.

VERÍSSIMO, Érico. O Tempo e o Vento. 9a ed. Porto Alegre: Globo, 1979.

WILLIAMS, Raymond. Marxismo e literatura. Rio de Janeiro: Zahar Editores. 1979.

WILLIAMS. Raymond. O Campo e a Cidade. São Paulo: Cia das Letras, 1990. 